\title{
Safety and efficacy of LCZ696, a first-in-class angiotensin receptor neprilysin inhibitor, in Japanese patients with hypertension and renal dysfunction
}

\author{
Sadayoshi Ito ${ }^{1}$, Minoru Satoh ${ }^{2}$, Yuko Tamaki ${ }^{3}$, Hiromi Gotou ${ }^{3}$, Alan Charney ${ }^{4}$, Naoko Okino ${ }^{3}$, \\ Mizuki Akahori ${ }^{3}$ and Jack Zhang ${ }^{4}$
}

This 8-week, multi-center, open-label study assessed the safety and efficacy of LCZ696, a first-in-class angiotensin receptor neprilysin inhibitor, in Japanese patients with hypertension and renal dysfunction. Patients $(n=32)$ with mean sitting systolic blood pressure (msSBP) $\geqslant 140 \mathrm{~mm} \mathrm{Hg}$ (after a 2-5-week washout of previous antihypertensive medications) and estimated glomerular filtration rate (eGFR) $\geqslant 15$ and $<60 \mathrm{ml} \mathrm{min}^{-1} 1.73 \mathrm{~m}^{-2}$ received LCZ696 $100 \mathrm{mg}$ with an optional titration to 200 and $400 \mathrm{mg}$ in a sequential manner starting from Week 2 in patients with inadequate BP control (msSBP $\geqslant 130 \mathrm{~mm} \mathrm{Hg}$ and mean sitting diastolic blood pressure (msDBP) $\geqslant 80 \mathrm{~mm} \mathrm{Hg}$ ) and without safety concerns. Safety was assessed by monitoring and recording all adverse events (AEs) and change in potassium and creatinine. Efficacy was assessed as change from baseline in $\mathrm{msSBP} / \mathrm{msDBP}$. The mean baseline BP was $151.6 / 86.9 \mathrm{~mm} \mathrm{Hg}$, urinary albumin/creatinine ratio (UACR) geometric mean was $7.3 \mathrm{mg} \mathrm{mmol}^{-1}$ and eGFR was $\geqslant 30$ and $<60$ in $25(78.1 \%)$ patients and was $\geqslant 15$ and $<30$ in $7(21.9 \%)$ patients. Fourteen (43.8\%) patients reported at least one AE, which were mild in severity. No severe AEs or deaths were reported. There were no clinically meaningful changes in creatinine, potassium, blood urea nitrogen and eGFR. The geometric mean reduction in UACR was $15.1 \%$, and the mean reduction in $\mathrm{msSBP}$ and msDBP was $20.5 \pm 11.3$ and $8.3 \pm 6.3 \mathrm{~mm} \mathrm{Hg}$, respectively, from baseline to Week 8 end point. LCZ696 was generally safe and well tolerated and showed effective BP reduction in Japanese patients with hypertension and renal dysfunction without a decline in renal function.

Hypertension Research (2015) 38, 269-275; doi:10.1038/hr.2015.1; published online 19 February 2015

Keywords: angiotensin receptor neprilysin inhibitor; Japanese; LCZ696; renal dysfunction

\section{INTRODUCTION}

Hypertension is both a cause and a complication of chronic kidney disease (CKD). Hypertension causes functional and structural changes in the kidney and is a major risk factor for cardiovascular complications. ${ }^{1}$ In Japan, a nationwide database, which included $>45000$ patients with $\mathrm{CKD}$, showed a higher prevalence of hypertension in patients with CKD vs. non-CKD $(58 \%$ vs. $42 \%){ }^{2}$ As renal disease progression and blood pressure (BP) elevations are closely related to each other, management of hypertension is critical to reduce the risk of further loss of renal function and cardiovascular complications. $^{3}$

The Japanese Society of Hypertension (JSH 2014) and the Japanese Society of Nephrology (JSN 2013) guidelines recommend that in hypertensive CKD patients with diabetes mellitus or proteinuria a BP target is $<130 / 80 \mathrm{~mm} \mathrm{Hg}$ and the first choice is an antihypertensive agent acting on the renin-angiotensin system (RAS). In those with neither diabetes mellitus nor proteinuria, a target BP is
$<140 / 90 \mathrm{~mm} \mathrm{Hg}$ and the first-line choice is a calcium channel blocker, RAS inhibitor or diuretic., ${ }^{45}$ BP lowering and RAS inhibition are important methods for slowing progression of CKD. ${ }^{6}$ In Japan, despite the availability and use of several classes of antihypertensive agents, BP control was achieved in only $22 \%$ of hypertensive patients with comorbid CKD (BP target, $<130 / 80 \mathrm{~mm} \mathrm{Hg}$ ). Not only is the lower BP target more difficult to achieve but the proportion of patients achieving the target $\mathrm{BP}(<130 / 80 \mathrm{~mm} \mathrm{Hg})$ was significantly lower in CKD patients than in non-CKD patients $(35 \%$ vs. $44 \%){ }^{2}$

In hypertensive CKD patients, BP control is not achieved even though most patients take three antihypertensive agents. ${ }^{7} \mathrm{BP}$ control is suboptimal not only in Japan ${ }^{2}$ but also around the world. ${ }^{8,9}$ Salt and water retention, ${ }^{10}$ increased sympathetic nervous system activity, ${ }^{11}$ increased activity of RAS ${ }^{12}$ and reduced biological activity of nitric oxide systems ${ }^{13}$ are the key promoters of elevated BP in patients with CKD. Even when currently available antihypertensive medications are used, these mechanisms compensate each other to make BP control

${ }^{1}$ Division of Nephrology, Endocrinology and Vascular Medicine, Tohoku University Hospital, Miyagi, Japan; ${ }^{2}$ Kawasaki Medical School Hospital, Okayama, Japan; ${ }^{3}$ Novartis Pharma K.K., Tokyo, Japan and ${ }^{4}$ Novartis Pharmaceuticals Corporation, East Hanover, NJ, USA

Correspondence: Professor S Ito, Division of Nephrology, Endocrinology and Vascular Medicine, Tohoku University Hospital, 1-1, Seiryo-machi, Aoba-ku,, Sendai City, Miyagi 980-8574, Japan. 
difficult. Hence, there is a medical need to develop improved antihypertensive agents with favorable efficacy and safety profiles and the ability to slow progression of renal disease.

The natriuretic peptide (NP) system together with the RAS and sympathetic nervous system have an important role in cardiovascular and renal homeostasis. ${ }^{14,15}$ Neprilysin (NEP) degrades biologically active NPs, including atrial NP, B-type NP and C-type NP. ${ }^{16} \mathrm{NP}$ levels can be enhanced by inhibiting the enzyme NEP. NPs increase the concentration of cyclic guanosine $3^{\prime}, 5^{\prime}$ monophosphate (cGMP), stimulate diuresis, natriuresis and vasodilation and may have additional antifibrotic and antisympathetic effects. ${ }^{17,18}$ However, NEP also contributes to the breakdown of angiotensin. ${ }^{19}$ Thus NEP inhibition would increase angiotensin levels. Therefore, its full benefits may not be realized unless there is simultaneous suppression of the RAS.

NEP inhibition with simultaneous RAS inhibition increases the plasma concentrations of NPs and inhibits the RAS. These, in turn, regulate water and electrolyte balance by acting on the kidney to promote natriuresis and diuresis. ${ }^{20,21}$ In addition to these effects, NPs cause vasodilation by directly relaxing vascular smooth muscle to help further lower BP. ${ }^{22-24}$ Additionally, NPs have anti-inflammatory and antifibrotic effects by reducing collagen synthesis. ${ }^{25}$

LCZ696 is a first-in-class angiotensin receptor NEP inhibitor. After ingestion, LCZ696 delivers systemic exposure to sacubitril (AHU377), a NEP inhibitor pro-drug, and valsartan, an angiotensin receptor blocker (ARB). Sacubitril is then rapidly metabolized by non-specific esterases to the active NEP inhibitor LBQ657. RAS inhibition has beneficial effects on CKD. In addition to lowering BP, RAS inhibition is associated with reducing proteinuria and slowing the decline in glomerular filtration rate (GFR). ${ }^{26}$ Previous studies with LCZ696 have demonstrated significant reductions in office and ambulatory BP compared with valsartan ${ }^{27}$ or placebo ${ }^{27,28}$ in patients with mild-tomoderate hypertension. Considering the well-known beneficial cardiovascular and renal effects of RAS blockade as well as the potential benefits provided by NEP inhibition, LCZ696 with its multimodal mechanism of action is a promising therapeutic approach in patients with hypertension and renal dysfunction and may offer beneficial renal effects beyond BP lowering. The current study was designed to evaluate the safety and efficacy of LCZ696 in Japanese patients with hypertension and renal dysfunction (CKD, with a confirmed estimated glomerular filtration rate $(\mathrm{eGFR}) \geqslant 15$ and $<60 \mathrm{ml} \mathrm{min}^{-1} 1.73 \mathrm{~m}^{-2}$ ).

\section{METHODS}

\section{Study design}

This was an 8-week, multi-center, open-label, phase III study including a placebo run-in period of 2-5 weeks for treated patients (to wash out the effects of earlier antihypertensive agents) and 1-2 weeks for untreated patients and an 8-week treatment period with LCZ696 $100 \mathrm{mg}$, with an optional dose titration to 200 or $400 \mathrm{mg}$ based on the need to achieve BP control (Figure 1). Thirteen Japanese study sites participated in this study. The study protocol was reviewed and approved by the independent institutional review board for each center. The study was performed in accordance with the International Conference on Harmonization Guidelines for Good Clinical Practices, applicable local regulations, and the ethical principles of the Declaration of Helsinki. All participants provided written informed consent prior to study participation (Clinicaltrials. gov NCT01593787).

\section{Patients}

Japanese men or women aged $\geqslant 20$ years diagnosed with hypertension and moderate-to-severe renal dysfunction (eGFR $\geqslant 15$ and $<60 \mathrm{ml} \mathrm{min}^{-1}$ $1.73 \mathrm{~m}^{-2}$ ) were selected for the study. Patients with hypertension, either untreated (patients who had not been taking antihypertensive drugs for at least 4 weeks prior to screening) or treated with antihypertensive therapy for at least 4 weeks prior to screening, were included if they had mean sitting systolic blood pressure $(\mathrm{msSBP}) \geqslant 140 \mathrm{~mm} \mathrm{Hg}$ and $<180 \mathrm{~mm} \mathrm{Hg}$ at screening (untreated patients only) and after placebo run-in period (treated and untreated patients). Patients had to achieve a medication compliance rate of $\geqslant 80 \%$ during the placebo run-in period.

Patients were excluded if they had severe hypertension (msSBP $\geqslant 180 \mathrm{~mm} \mathrm{Hg}$ and/or mean sitting diastolic blood pressure (msDBP) $\geqslant 110 \mathrm{~mm} \mathrm{Hg}$ ), secondary hypertension (such as renovascular hypertension except renal parenchymal hypertension), history of angioedema, type 1 or type 2 diabetes mellitus that was not well controlled based on the investigator's clinical judgment, patients on dialysis, eGFR $<15 \mathrm{ml} \mathrm{min}^{-1} 1.73 \mathrm{~m}^{-2}$, patients with acute renal failure or end-stage renal disease. Other exclusion criteria included history of significant cardiovascular/cerebrovascular disease; previous or current diagnosis of heart failure; or any significant laboratory abnormalities at screening such as serum potassium $>5.5$ or $<3.5 \mathrm{mEql}^{-1}$, serum sodium $<130 \mathrm{mEql}^{-1}$ or alanine aminotransferase or aspartate aminotransferase $>2$ times the upper limit of the normal range.

\section{Treatment}

Treatment was initiated with low dose LCZ696 (100 mg) once-daily followed by a stepwise optional dose titration to LCZ696 200 and $400 \mathrm{mg}$. For patients whose BP was not adequately controlled with LCZ696 $100 \mathrm{mg}$ (msBP $\geqslant 130$ $180 \mathrm{~mm} \mathrm{Hg}$ ) after 2 weeks of treatment and who had no safety concerns (serum potassium $>5.5 \mathrm{mEq}^{-1}$, increase in serum creatinine by $\geqslant 20 \%$ from baseline

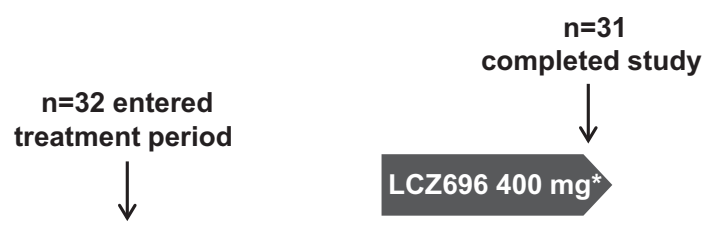

LCZ696 200 mg*

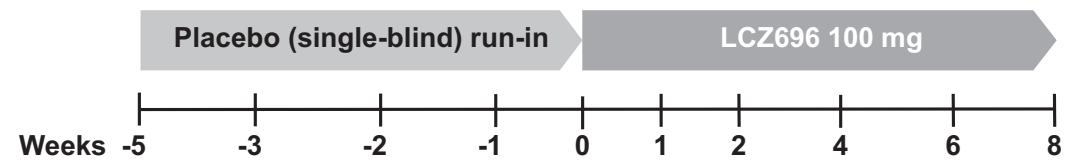

*Dose titration for inadequately controlled blood pressure (msDBP $\geq 80 \mathrm{~mm} \mathrm{Hg}$ or msSBP $\geq 130 \mathrm{~mm} \mathrm{Hg}$ ) and no safety concerns (serum potassium level $>5.5 \mathrm{mEq} / \mathrm{L}$ and increase in serum creatinine $\geq 20 \%$ ) or a potential safety problem related to an increase in the study drug

Figure 1 Study design. 
or a potential safety problem related to an increase in the study drug), LCZ696 was uptitrated to $200 \mathrm{mg}$ once daily and if patients still remained inadequately controlled after 4 weeks of treatment, then the dose was uptitrated to $400 \mathrm{mg}$ once daily.

Doses were taken in the morning, before or after a meal except on the days of scheduled visits when LCZ696 was administered after the completion of all assessments. Patients who were taking two or more antihypertensive agents before the initiation of the study continued to take one agent (other than ARB, angiotensin-converting enzyme inhibitor (ACEI) or a fixed combination containing ARB or ACEI) concurrently, as long as there was no change in the drug or the dosing regimen during the study. Concomitant use of other antihypertensive agents was not permitted from the start of the run-in period (untreated patients) or for 2 weeks after the beginning of the run-in period (treated patients) to the end of the treatment period.

\section{Safety assessments}

The primary objective was safety and tolerability, which included monitoring and recording adverse events (AEs), serious AEs, laboratory tests for hematology, blood chemistry and urinalysis and monitoring vital signs, ECG and body weight. Standard laboratory tests were performed at baseline (Week 0) and at Weeks 4 and 8 during the treatment period. In addition, serum creatinine, blood urea nitrogen and serum electrolytes (sodium and potassium) were measured at Weeks 1, 2 and 6 during the treatment period. Random or spot urine samples were collected in the physician's office for urine creatinine and albumin at baseline and at the end of the study for the calculation of the urinary albumin/creatinine ratio (UACR). The eGFR $\left(\mathrm{ml} \mathrm{min}^{-1} 1.73 \mathrm{~m}^{-2}\right)$ was calculated based on the result of serum creatinine, using the formula eGFR = $194 \times \mathrm{Cr}^{-1.094} \times \mathrm{age}^{-0.287}(\times 0.739$; females $){ }^{29}$ The incidence of AEs was reported by eGFR category.

\section{Efficacy assessments}

The efficacy outcome was the change in $\mathrm{msSBP} / \mathrm{msDBP}$ from baseline (Week 0 ) to Week 8 (last observation carried forward). BP was measured at trough (approximately $24 \mathrm{~h}$ after dosing after the previous day's dosing and immediately before the same day's dosing) at all scheduled visits. An automated and validated BP measuring device (Omron BP monitor: HEM-7080IC, manufactured by OMRON HEALTHCARE Co., Ltd, Kyoto, Japan) with the appropriate cuff size was used in accordance with British Hypertension Society 2004 guidelines. ${ }^{30} \mathrm{BP}$ measurements were taken four times at 2-min intervals after resting for at least $5 \mathrm{~min}$ in the sitting position. The reported BP for the visit was the mean of all these readings. Additional assessments included BP control rate (proportion of patients with $\mathrm{BP}<130 / 80 \mathrm{~mm} \mathrm{Hg}$ ), SBP responder rate (proportion of patients with $\mathrm{SBP}<130 \mathrm{~mm} \mathrm{Hg}$ or $\geqslant 20 \mathrm{~mm} \mathrm{Hg}$ reduction from baseline) and DBP responder rate (proportion of patients with $\mathrm{DBP}<80 \mathrm{~mm}$ $\mathrm{Hg}$ or $\geqslant 10 \mathrm{~mm} \mathrm{Hg}$ reduction from baseline). The change from baseline in UACR was also assessed. The efficacy parameters were reported by eGFR category as well.

\section{Pharmacokinetic assessments}

LCZ696 delivers systemic exposure to a NEP inhibitor pro-drug AHU377 (which converts to an active form LBQ657) and valsartan. Trough plasma concentrations of valsartan, AHU377 and LBQ657 were measured at the visits when LCZ696 dose was increased and at Week 8 (or discontinuation). Blood samples were drawn from a forearm vein into EDTA-containing polyethylene tubes and were centrifuged at $1500 \mathrm{~g}$ for $10 \mathrm{~min}$. Plasma was stored at $\leqslant-15{ }^{\circ} \mathrm{C}$ until the analyses were performed. The concentrations of valsartan, AHU377 and LBQ657 were determined by liquid chromatography/tandem mass spectrometry. The lower limit of quantification was $10.0 \mathrm{ng} \mathrm{ml}^{-1}$ for valsartan, $1.0 \mathrm{ng} \mathrm{ml}^{-1}$ for AHU377 and $20.0 \mathrm{ng} \mathrm{ml}^{-1}$ for LBQ657.

\section{Statistical analyses}

A total of 56 enrolled patients were planned to achieve a sample size of 25 patients completing the 8-week treatment period, assuming a drop-out rate of $50 \%$ prior to the treatment period and $10 \%$ during the treatment period. This sample size was considered sufficient to evaluate the overall safety and tolerability of LCZ696 treatment, with an $84 \%$ chance to observe at least one
$\mathrm{AE}$, when the true incidence of an individual $\mathrm{AE}$ is $7 \%$. Safety analyses were performed on the safety set, consisting of all patients who received at least one dose of LCZ696. Efficacy analyses were performed on the full analysis set, consisting of all patients who entered the treatment period of the study. Descriptive statistics were used for all efficacy and safety variables. Last observation carried forward method was used to assess the changes from baseline to Week 8 end point.

\section{RESULTS}

\section{Patient disposition and characteristics}

Of the 39 patients who entered the placebo run-in period, 32 patients entered the treatment period and 31 (96.9\%) patients completed the study. All 32 patients were exposed to LCZ696 and were evaluable for safety, efficacy and pharmacokinetic analyses. Of the 32 patients, $81 \%$ $(n=26)$ of patients had their LCZ696 dose increased from 100 to $200 \mathrm{mg}$ and $56 \%(n=18)$ of patients were uptitrated to $400 \mathrm{mg}$. All the patients were Japanese with a mean age of 65.8 years; 21 patients $(65.6 \%)$ were elderly ( $\geqslant 65$ years age); 25 patients $(78.1 \%)$ had stage III (eGFR $\geqslant 30$ and $<60 \mathrm{ml} \mathrm{min}^{-1} 1.73 \mathrm{~m}^{-2}$ ); and 7 patients $(21.9 \%$ ) had stage IV (eGFR $\geqslant 15$ and $<30 \mathrm{ml} \mathrm{min}^{-1} 1.73 \mathrm{~m}^{-2}$ ) CKD. The mean duration of hypertension was 9.4 years. Patient baseline characteristics are presented in Table 1. During the study, 14 of the 32 patients used antihypertensive medication (other than ARB, ACEI or a fixed combination of ARB and ACEI) at baseline (Day 1) that continued throughout the study; Of these, calcium channel blockers were taken by 12 of the 14 patients and diuretics by 2 of the 14 patients.

\section{Safety and tolerability}

LCZ696 was safe and well tolerated during the 8-week treatment in patients with hypertension and renal dysfunction. AEs were reported by 14 patients $(43.8 \%)$, and all were mild in severity. The most frequently reported $\mathrm{AE}$ was nasopharyngitis (6 patients, 18.8\%)

\section{Table 1 Patient baseline characteristics}

\begin{tabular}{|c|c|}
\hline Characteristics & $N=32$ \\
\hline Age (years) & $65.8 \pm 9.1$ \\
\hline Aged $\geqslant 65$ years, $n(\%)$ & $21(65.6)$ \\
\hline Male, n (\%) & $24(75.0)$ \\
\hline BMI $\left(\mathrm{kg} \mathrm{m}^{-2}\right)$ & $25.3 \pm 3.3$ \\
\hline msDBP (mm Hg) & $86.9 \pm 10.8$ \\
\hline msSBP (mm Hg) & $151.6 \pm 10.3$ \\
\hline Duration of hypertension (years) & $9.4 \pm 6.4$ \\
\hline Diabetes, $n(\%)$ & $6(18.8)$ \\
\hline eGFR (ml min $\left.{ }^{-1} 1.73 \mathrm{~m}^{-2}\right)$ & $41.0 \pm 10.1$ \\
\hline \multicolumn{2}{|l|}{ eGFR group, $n(\%)$} \\
\hline$\geqslant 15$ to $<30 \mathrm{ml} \mathrm{min}^{-1} 1.73 \mathrm{~m}^{-2}$ & $7(21.9)$ \\
\hline$\geqslant 30$ to $<60 \mathrm{ml} \mathrm{min}^{-1} 1.73 \mathrm{~m}^{-2}$ & $25(78.1)$ \\
\hline UACR (mg mmol-1), geometric mean & 7.3 \\
\hline Creatinine (umol I-1) & $122.4 \pm 35.4$ \\
\hline BUN (mmoll-1) & $7.1 \pm 2.2$ \\
\hline Sodium (mmol $\mathrm{I}^{-1}$ ) & $143.0 \pm 1.8$ \\
\hline Potassium (mmol $\mathrm{I}^{-1}$ ) & $4.6 \pm 0.3$ \\
\hline
\end{tabular}

Abbeviations: BMI, body mass index; BUN, blood urea nitrogen; eGFR, estimated glomerular filtration rate; $\mathrm{msDBP}$, mean sitting diastolic blood pressure; msSBP, mean sitting systolic blood pressure; UACR, urinary albumin-to-creatinine ratio.

pressure; UACR, urinary albumin-to-creatinine ratio.
Data are presented as mean \pm s.d. unless otherwise specified. Data are presented as mean \pm s.d. un
UACR: $1 \mathrm{mg} \mathrm{mmol}^{-1}=8.85 \mathrm{mgg}^{-1}$ 
(Table 2). Two AEs, headache and pruritus, each reported by one patient were considered as possibly related to the study drug, and the patient who reported headache prematurely discontinued the study. No death or serious AE was reported in the study. There were no cases of dizziness, hypotension or other events related to low BP. No cases of angioedema were reported. The incidence of AEs was 57.1\% (4/7 patients) and $40.0 \%$ (10/25 patients) in patients with eGFR values $<30$ and $\geqslant 30 \mathrm{ml} \mathrm{min}^{-1} 1.73 \mathrm{~m}^{-2}$, respectively.

The mean changes in clinical chemistry parameters from baseline to Week 2 and Week 8 end point were small and not clinically meaningful (Table 3). The median value for changes in laboratory parameters from baseline to Week 2 and Week 8 end point were: serum creatinine $\left(-0.5 \mu \mathrm{mol}^{-1}\right.$ and $\left.2.0 \mu \mathrm{mol} \mathrm{l}^{-1}\right)$, blood urea nitrogen $\left(0.0\right.$ and $\left.0.4 \mathrm{mmoll}^{-1}\right)$, serum sodium $\left(0.0 \mathrm{mmoll}^{-1}\right)$, serum potassium $\left(0.0 \mathrm{mmoll}^{-1}\right)$, and eGFR $\left(0.1 \mathrm{ml} \mathrm{min}^{-1} 1.73 \mathrm{~m}^{-2}\right.$ and $\left.-0.6 \mathrm{ml} \mathrm{min}^{-1} 1.73 \mathrm{~m}^{-2}\right)$. Clinically notable changes in blood urea nitrogen $(>50 \%$ increase from baseline) were observed in 6 patients (18.8\%); these values remained in the normal range

\section{Table 2 Safety and tolerability profile of LCZ696}

\begin{tabular}{lc}
\hline Adverse events & Total $(\mathrm{n}(\%), \mathrm{N}=32$ \\
\hline Any adverse event & $14(43.8)$ \\
Nasopharyngitis & $6(18.8)$ \\
Conjunctivitis allergic & $1(3.1)$ \\
Constipation & $1(3.1)$ \\
Cystitis & $1(3.1)$ \\
Gout & $1(3.1)$ \\
Headache & $1(3.1)$ \\
Oedema peripheral & $1(3.1)$ \\
Thermal burn & $1(3.1)$ \\
Arthralgia & $1(3.1)$ \\
Dyspepsia & $1(3.1)$ \\
Pruritus & $1(3.1)$ \\
Supraventricular extrasystoles & $1(3.1)$ \\
Toothache & $1(3.1)$ \\
$\quad>130$ &
\end{tabular}

Table 3 Mean change in clinical chemistry from baseline to Week 2 and Week 8 end point

\begin{tabular}{|c|c|c|}
\hline Variable & Week 2 end point & Week 8 end point \\
\hline Creatinine (umol I-1) & $0.5 \pm 8.5$ & $1.9 \pm 11.5$ \\
\hline BUN (mmol I-1) & $0.1 \pm 1.4$ & $0.2 \pm 1.6$ \\
\hline Sodium (mmoll-1) & $0.0 \pm 1.7$ & $-0.3 \pm 2.1$ \\
\hline Potassium (mmol I-1) & $0.0 \pm 0.3$ & $-0.1 \pm 0.3$ \\
\hline eGFR (ml min-1 $\left.1.73 \mathrm{~m}^{-2}\right)$ & $-0.2 \pm 3.4$ & $-0.5 \pm 5.4$ \\
\hline
\end{tabular}

(2.9-8.2 $\left.\mathrm{mmoll}^{-1}\right)$ for 1 patient $(3.1 \%)$ but were above the normal range for 5 patients $(15.6 \%)$. A $>5 \%$ decrease in serum sodium was observed in 1 patient $(3.1 \%)$. One patient had serum potassium $>5.5 \mathrm{mmoll}^{-1}$ at Week 4 , but the serum potassium returned to normal at Week 6 without interrupting study medication (Table 2).

\section{Efficacy}

The $\mathrm{msSBP} \pm$ s.d. was reduced from $151.6 \pm 10.3 \mathrm{~mm} \mathrm{Hg}$ at baseline to $138.2 \pm 12.1 \mathrm{~mm} \mathrm{Hg}$ at Week 2, followed by a further decrease to $132.2 \pm 10.8 \mathrm{~mm} \mathrm{Hg}$ at Week 4, which remained stable thereafter at Week $6(132.5 \pm 13.1 \mathrm{~mm} \mathrm{Hg})$ and at Week $8(131.2 \pm 11.1 \mathrm{~mm} \mathrm{Hg})$. The mean \pm s.d. decrease in msSBP from baseline to Week 8 end point was $20.5 \pm 11.3 \mathrm{~mm} \mathrm{Hg}$ (Figure 2). The msDBP was reduced from $86.9 \pm 10.8 \mathrm{~mm} \mathrm{Hg}$ at baseline to $81.7 \pm 10.1 \mathrm{~mm} \mathrm{Hg}$ at Week 2, followed by a further decrease to $80.1 \pm 10.0 \mathrm{~mm} \mathrm{Hg}$ at Week 4 and $79.4 \pm 10.4 \mathrm{~mm} \mathrm{Hg}$ at Week 6 and remained stable until Week 8 $(78.8 \pm 10.7 \mathrm{~mm} \mathrm{Hg})$. Mean \pm s.d. decrease in msDBP from baseline to Week 8 end point was $8.3 \pm 6.3 \mathrm{~mm} \mathrm{Hg}$ (Figure 2).

Baseline $\mathrm{msSBP} / \mathrm{msDBP}$ were $149.8 / 83.9 \mathrm{~mm} \mathrm{Hg}$ for eGFR $<30 \mathrm{ml} \mathrm{min}^{-1} 1.73 \mathrm{~m}^{-2}$ and $152.1 / 87.7 \mathrm{~mm} \mathrm{Hg}$ for eGFR $\geqslant 30 \mathrm{ml} \mathrm{min}^{-1} 1.73 \mathrm{~m}^{-2}$. The $\mathrm{msSBP} / \mathrm{msDBP}$ reduction at Week 8 end point was clinically significant for both subgroups; $17.7 / 5.5 \mathrm{~mm} \mathrm{Hg}$ for eGFR $<30 \mathrm{ml} \mathrm{min}^{-1} 1.73 \mathrm{~m}^{-2}$ and 21.3/9.1 mm$\mathrm{Hg}$ for $\mathrm{eGFR} \geqslant 30 \mathrm{ml} \mathrm{min}^{-1} 1.73 \mathrm{~m}^{-2}$. The overall BP control rate $(<130 / 80 \mathrm{~mm} \mathrm{Hg}$ ) was $25.0 \%$ at the Week 8 end point. The SBP and DBP control rates were $50.0 \%$ and $46.9 \%$ at Week 8 end point. A successful SBP response rate (proportion of patients with $\mathrm{SBP}<130$ $\mathrm{mm} \mathrm{Hg}$ or $\geqslant 20 \mathrm{~mm} \mathrm{Hg}$ reduction from baseline) and DBP response rate (proportion of patients with $\mathrm{DBP}<80 \mathrm{~mm} \mathrm{Hg}$ or $\geqslant 10 \mathrm{~mm} \mathrm{Hg}$ reduction from baseline) was achieved by $59.4 \%$ and $71.9 \%$ of patients, respectively, at the Week 8 end point.

BP control at Week 8 end point was achieved by $28.6 \%$ of patients with eGFR $<30 \mathrm{ml} \mathrm{min}^{-1} 1.73 \mathrm{~m}^{-2}$ and by $24.0 \%$ of patients with eGFR $\geqslant 30 \mathrm{ml} \mathrm{min}^{-1} 1.73 \mathrm{~m}^{-2}$. The SBP and DBP control rates were $57.1 \%$ and $42.9 \%$ in patients with eGFR $<30 \mathrm{ml} \mathrm{min}^{-1} 1.73 \mathrm{~m}^{-2}$ while $48.0 \%$ of patients with eGFR $\geqslant 30 \mathrm{ml} \mathrm{min}^{-1} 1.73 \mathrm{~m}^{-2}$ achieved both SBP and DBP control. Both SBP and DBP response was achieved by $57.1 \%$ of patients with eGFR $<30 \mathrm{ml} \mathrm{min}^{-1} 1.73 \mathrm{~m}^{-2}$, whereas the SBP and DBP response was $60.0 \%$ and $76.0 \%$ in patients with $\mathrm{eGFR} \geqslant 30 \mathrm{ml} \mathrm{min}^{-1} 1.73 \mathrm{~m}^{-2}$.

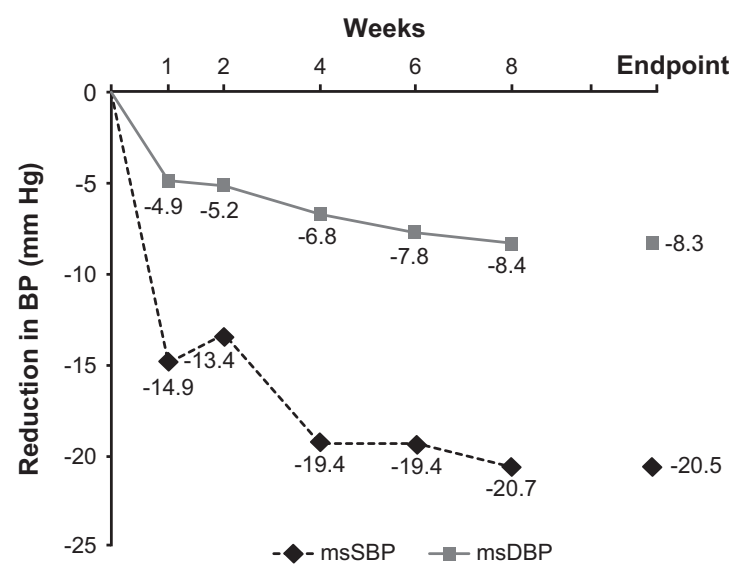

Endpoint is Week 8 using the last observation carried forward approach. msDBP, mean sitting diastolic blood pressure; msSBP, mean sitting systolic blood pressure.

Figure 2 Mean change in mean sitting blood pressure from baseline to Week 8 end point with LCZ696. 


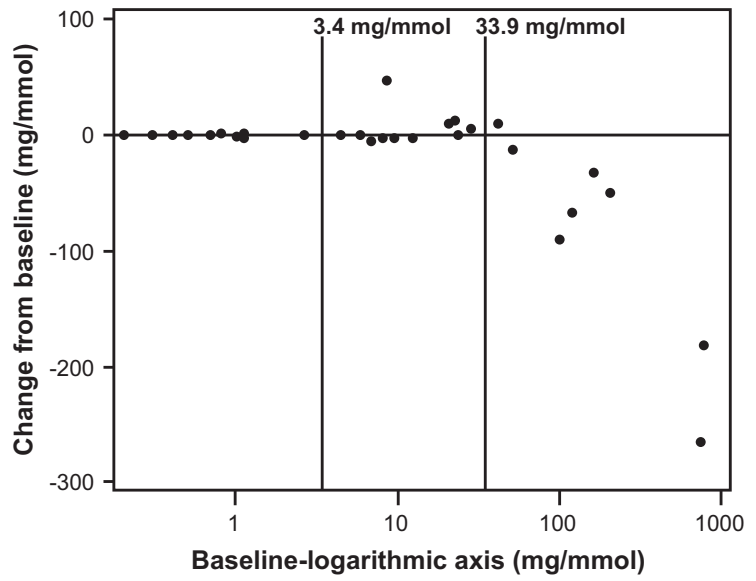

UACR, urinary albumin/creatinine ratio, normoalbuminuria: $<3.4 \mathrm{mg} / \mathrm{mmol}$, microalbuminuria $3.4-33.9 \mathrm{mg} / \mathrm{mmol}$, macroalbuminuria $>33.9 \mathrm{mg} / \mathrm{mmol}$, UACR: $1 \mathrm{mg} / \mathrm{mmol}=8.85 \mathrm{mg} / \mathrm{g}$

Figure 3 Scatter plot (baseline vs. change) of UACR.

Treatment with LCZ696 showed a geometric mean reduction of $15.1 \%$ in UACR from baseline. The geometric mean value of UACR decreased from $7.3 \mathrm{mg} \mathrm{mmol}^{-1}$ at baseline to $6.2 \mathrm{mg} \mathrm{mmol}^{-1}$ at Week 8 end point. Reduction from baseline in UACR in patients with baseline UACR $>33.9 \mathrm{mg} \mathrm{mmol}^{-1}$ (macroalbuminuria) was larger than those with baseline UACR $<3.4 \mathrm{mg} \mathrm{mmol}^{-1}$ (normoalbuminuria) and 3.4-33.9 $\mathrm{mg} \mathrm{mmol}^{-1}$ (microalbumiuria) (Figure 3).

\section{Pharmacokinetics}

A dose-related increase in trough plasma levels of LBQ657 and valsartan were observed from LCZ696 100-400 mg. After the administration of LCZ696 100, 200 and $400 \mathrm{mg}$, mean trough plasma levels at Week 8 were 2162, 6404 and $8567 \mathrm{ng} \mathrm{ml}^{-1}$ for LBQ657 and 141, 548 and $591 \mathrm{ng} \mathrm{ml}^{-1}$ for valsartan respectively. Dose-normalized trough plasma LBQ657 concentrations tended to increase according to the decrease in eGFR (Supplementary Figure S1). This was not the case for valsartan. The increases of dose-normalized trough plasma LBQ657 concentrations were unaffected by age.

\section{DISCUSSION AND CONCLUSIONS}

Previous data have shown that LCZ696 produced significantly greater reductions in SBP, DBP, pulse pressure and a greater $\mathrm{BP}$ control rate and $\mathrm{BP}$ response rate than valsartan $(\mathrm{ARB})$ and $\mathrm{AHU}$ (NEP inhibitor) in mostly Caucasian patients with mild-moderate hypertension, supporting the complementary mechanism of action of ARB and NEP inhibition in lowering blood pressure. ${ }^{27}$ This was the first study to evaluate the safety and efficacy of LCZ696 in Japanese patients with hypertension and renal dysfunction. In this patient population, LCZ696 was generally safe and well tolerated during the 8-week treatment, with only one patient discontinuing the study. There were no cases of death, serious AEs, dizziness, hypotension or angioedema during the study. The study demonstrated no clinically important effects of LCZ696 on renal function or serum potassium despite varying levels of renal function and the large reduction in BP during the first weeks of treatment in these hypertensive patients with CKD. The minimal changes in serum potassium observed in this study are consistent with previous LCZ696 studies in patients with hypertension (unpublished data) as well as healthy volunteers and in patients with chronic heart failure. ${ }^{31,32}$ The small initial reduction in eGFR that was observed is typically associated with RAS blockade using standard doses of ACEI or ARB. ${ }^{33}$ The antihypertensive effect of LCZ696 was evident during the first 2 weeks of treatment, and there were further incremental reductions in msSBP and $\mathrm{msDBP}$ by Week 4 , remaining stable thereafter until the Week 8 end point.

The reduction in UACR observed in the present study is comparable to a previous LCZ696 study in patients with mild-to-moderate hypertension that showed 10, 4 and $12 \%$ reductions in UACR with 100, 200 and $400 \mathrm{mg}$ LCZ696 doses, respectively, from baseline to Week $8 .^{27}$ In the present study, reduction in UACR was greater in patients with macroalbuminuria than in patients with normoalbuminuria or microalbuminuria. This is a similar response to what is reported with RAS inhibitors in subjects with high urinary protein excretion. ${ }^{34}$ In patients with preserved ejection fraction heart failure, therapy with LCZ696 for 36 weeks preserved renal function (as indicated by a smaller $1.6 \mathrm{ml} \mathrm{min} \mathrm{min}^{-1} 1.73 \mathrm{~m}^{-2}$ decrease in eGFR $v s$. $5.2 \mathrm{ml} \mathrm{min}^{-1} 1.73 \mathrm{~m}^{-2}$ decrease in the valsartan group). Although this was accompanied by a small $\left(1.0 \mathrm{mg} \mathrm{mmol}{ }^{-1}\right)$ increase in UACR from baseline, ${ }^{35}$ this increase is well within the variability of the measurement and the day-to-day variability of urinary albumin excretion.

JSH 2014 and JSN 2013 guidelines recommend RAS inhibitors as a first therapeutic choice for CKD patients with diabetes mellitus or proteinuria. ${ }^{4,5}$ Several studies have shown that valsartan was well tolerated and effective in treating patients with hypertension and CKD. Treatment with valsartan resulted in slightly greater decreases in total protein, albumin excretion and eGFR as compared with placebo. ${ }^{36}$ In general, therapy with an ACEI or an ARB is associated with an increase in serum creatinine concentration in patients with renal dysfunction. This is generally attributed to decreased glomerular capillary pressure because of preferential vasodilation of efferent arterioles as compared with afferent arterioles. ${ }^{37}$ However, in the current study only small and non-progressive increases in the serum creatinine concentration accompanied effective reduction in BP with LCZ696. This may indicate that LCZ696 exerts favorable effects on renal function. These findings suggest that NEP inhibition, in the presence of angiotensin II receptor blockade as provided by LCZ696, preserves GFR by maintaining glomerular capillary pressure despite reductions in BP. This is consistent with an NPs' preferential vasodilator action on the afferent arteriole. NPs also inhibit sodium reabsorption in both the proximal and distal nephron that increases urinary sodium excretion and urine flow. This effect has an important role in regulating tubuloglomerular feedback, which also prevents the decrease in GFR that normally follows increased salt delivery to the distal tubule. ${ }^{20}$

There is a great need to control the BP in patients with renal dysfunction as previous studies conducted in Asia and Japan have demonstrated a linear and continuous association between BP and renal outcomes even in subjects with prehypertension. ${ }^{38,39}$ LCZ696 (100-400 mg) showed clinically significant reductions in msSBP and msDBP from Week 1 to the end of the study. BP control was achieved by $25 \%$ of patients, which is in accordance with previous studies from different regions (Spain, US and Norway) where $\mathrm{BP}<130 / 80 \mathrm{~mm} \mathrm{Hg}$ was achieved in $13-37 \%$ of patients with CKD. The lack of optimal BP control in these regions was mainly attributed to lack of control of systolic BP. ${ }^{40-42}$ In our study, $50 \%$ of patients achieved $\operatorname{msSBP}<130$ $\mathrm{mm} \mathrm{Hg}$ at end point from a baseline $\mathrm{msSBP}$ of $151.6 \mathrm{~mm} \mathrm{Hg}$. A previous study has shown that, in patients with CKD, SBP is associated with an increased rate of progression of kidney disease, and controlling SBP to $110-129 \mathrm{~mm} \mathrm{Hg}$ reduces the risk of kidney disease progression. ${ }^{43,44}$ Considering the absence of add-on antihypertensive therapy in our study, the BP control rates achieved with LCZ696 compare well with other studies of BP control in patients with CKD. ${ }^{40-42}$ 
We speculate that the excellent BP-lowering effect of LCZ696 may be accompanied by the action of NPs to increase renal medullary blood flow. ${ }^{45}$ When systemic BP decreases, renal medullary blood flow decreases (unlike cortical blood flow, which is maintained by autoregulation). This decrease in medullary blood flow, in turn, promotes sodium reabsorption, thereby blunting the BP-lowering effects of antihypertensive drugs. Thus LCZ696 may be a unique antihypertensive drug with multiple modes of action, namely inhibiting the RAS, directly vasodilating vascular smooth muscle cells and causing natriuresis induced by both direct tubular actions and increases in medullary blood flow.

In the present study in patients with renal dysfunction, mean trough plasma LCZ696 concentrations increased with dose. A correlation was observed between renal function and systemic exposure to LBQ657 but not to valsartan. This reduction in LBQ657 clearance was expected, because LBQ657 is primarily eliminated in the urine with a circulating half-life of $12 \mathrm{~h} .{ }^{31}$ Although no safety issues were noted in this study, the clinical significance of these increases in LBQ657 exposure in patients with renal dysfunction remains to be determined. The overall safety profile reported in hypertensive patients with moderate or severe renal impairment in the present study treated with LCZ696 doses up to $400 \mathrm{mg}$ were similar to those of patients with mild or moderate hypertension in previous studies. ${ }^{27,28}$ Additionally, favorable antihypertensive effects were produced by LCZ696 in hypertensive patients with renal impairment in this study, regardless of the degree of renal impairment. Thus hypertensive patients with renal impairment can be treated with the same dose and regimen used in hypertensive patients with normal renal function.

Our results suggest that LCZ696 may be a promising therapeutic approach in patients with hypertension and renal dysfunction and may offer beneficial renal effects in addition to BP lowering. In addition to the cardiovascular and renal benefits of AT1 receptor blockade, LCZ696 provides NEP inhibition, which enhances the actions of NPs. These peptides promote natriuresis and diuresis and inhibit the sympathetic nervous system and aldosterone secretion. NPs also may provide renal protection in patients with renal dysfunction by reducing intraglomerular pressure and through antiproliferative and antihypertrophic effects. Potential limitations of this study include its open-label design, small sample size and relatively short duration. However, this 8-week study has demonstrated that LCZ696, a first-inclass angiotensin receptor NEP inhibitor, is generally safe and efficacious in Japanese patients with hypertension and renal dysfunction while maintaining renal function. Additional studies are needed to confirm the beneficial effects and safety profile of LCZ696 observed in this trial.

\section{CONFLICT OF INTEREST}

YT, HG, AC, NO, MA and JZ are employees of Novartis Pharmaceutical Corporation and may receive $\geqslant 1000000$ yen (in one year) for employment. SI received lecture fee and consultant fee from various Japanese pharmaceutical companies, including Novartis. MS has no conflict of interest to disclose.

\section{ACKNOWLEDGEMENTS}

Novartis is the sponsor of this study and prepared the study protocol. This study was supported by Novartis. All authors participated in the development and writing of the paper and approved the final manuscript for publication. The authors take full responsibility for the content of the paper and thank Hyosung Kim for statistical analysis (who was an employee of Novartis at the time of study completion and statistical analysis), Sandra Thompson for statistical review (who was an employee of Novartis at the time of statistical analysis) and Dr Madhavi Dokku (Novartis Healthcare) for assisting in the writing of this manuscript, collating comments from all authors and editing the final manuscript. We also thank all the clinical investigators and study coordinators at the participating centers (Shinagawa East one Medical Clinic, Miho Clinic, Minamino Heart Clinic, Koukan Clinic, Motomachi Takatsuka Naika Clinic, Anbe Heart Clinic, Ikeoka Clinic, Sapporo Century Hospital, Yoshida Memorial Hospital, Kotoni Medical Support Clinic, Kawahara Nephro-urological Clinic, Tohoku University Hospital, Kawasaki Medical School Hospital) and especially all the patients who participated in the study.

1 Weber MA, Schiffrin EL, White WB, Mann S, Lindholm LH, Kenerson JG, Flack JM, Carter BL, Materson BJ, Ram CV, Cohen DL, Cadet JC, Jean-Charles RR, Taler S, Kountz D, Townsend R, Chalmers J, Ramirez AJ, Bakris GL, Wang J, Schutte AE, Bisognano JD, Touyz RM, Sica D, Harrap SB. Clinical practice guidelines for the management of hypertension in the community a statement by the American Society of Hypertension and the International Society of Hypertension. J Hypertens 2014; 32: $3-15$

2 Konta T, Ikeda A, Ichikawa K, Fujimoto S, Iseki K, Moriyama T, Yamagata K, Tsuruya K, Yoshida H, Asahi K, Kurahashi I, Ohashi Y, Watanabe T. Blood pressure control in a Japanese population with chronic kidney disease: a baseline survey of a nationwide cohort. Am J Hypertens 2012; 25: 342-347.

3 Yano Y, Fujimoto S, Sato Y, Konta T, Iseki K, Moriyama T, Yamagata K, Tsuruya K, Yoshida H, Asahi K, Kurahashi I, Ohashi Y, Watanabe T. Association between prehypertension and chronic kidney disease in the Japanese general population. Kidney Int 2012; 81: 293-299.

4 Japan nephrology society. [Special issue: evidence-based practice guideline for the treatment of CKD (Japanese article)]. Nihon Jinzo Gakkai Shi 2013; 55: 585-860.

5 Shimamoto K, Ando K, Fujita T, Hasebe N, Higaki J, Horiuchi M, Imai Y, Imaizumi T, Ishimitsu $\mathrm{T}$, Ito $\mathrm{M}$, Ito $\mathrm{S}$, Itoh $\mathrm{H}$, Iwao $\mathrm{H}$, Kai H, Kario K, Kashihara N, Kawano $\mathrm{Y}$ Kim-Mitsuyama S, Kimura G, Kohara K, Komuro I, Kumagai H, Matsuura H, Miura K, Morishita R, Naruse M, Node K, Ohya Y, Rakugi H, Saito I, Saitoh S, Shimada K, Shimosawa T, Suzuki H, Tamura K, Tanahashi N, Tsuchihashi T, Uchiyama M, Ueda S, Umemura S. The Japanese Society of Hypertension Guidelines for the Management of Hypertension (JSH 2014). Hypertens Res 2014; 37: 253-387.

6 Drawz PE, Rosenberg ME. Slowing progression of chronic kidney disease. Kidney Int Suppl (2011) 2013; 3: 372-376.

7 Sarafidis PA, Sharpe CC, Wood E, Blacklock R, Rumjon A, AI-Yassin A, Ariyanayagam R, Simmonds S, Fletcher-Rogers J, Vinen K. Prevalence, patterns of treatment, and control of hypertension in predialysis patients with chronic kidney disease. Nephron Clin Pract 2012; 120: c147-c155.

8 Fraser SD, Roderick PJ, McIntyre NJ, Harris S, Mclntyre CW, Fluck RJ, Taal MW Suboptimal blood pressure control in chronic kidney disease stage 3: baseline data from a cohort study in primary care. BMC. Fam Pract 2013; 14: 88

9 Plantinga LC, Miller ER III, Stevens LA, Saran R, Messer K, Flowers N, Geiss L, Powe NR. Blood pressure control among persons without and with chronic kidney disease: US. trends and risk factors 1999-2006. Hypertension 2009; 54: 47-56.

10 Charra B. Fluid balance, dry weight, and blood pressure in dialysis. Hemodial Int 2007; 11: 21-31.

11 Klein IH, Ligtenberg G, Neumann J, Oey PL, Koomans HA, Blankestijn PJ. Sympathetic nerve activity is inappropriately increased in chronic renal disease. J Am Soc Nephrol 2003; 14: 3239-3244.

12 Rüster C, Wolf G. Renin-angiotensin-aldosterone system and progression of renal disease. J Am Soc Nephrol 2006; 17: 2985-2991.

13 Fliser D, Kronenberg F, Kielstein JT, Morath C, Bode-Böger SM, Haller H, Ritz E. Asymmetric dimethylarginine and progression of chronic kidney disease: the mild to moderate kidney disease study. J Am Soc Nephrol 2005; 16: 2456-2461.

14 Kalra PR, Anker SD, Coats AJ. Water and sodium regulation in chronic heart failure: the role of natriuretic peptides and vasopressin. Cardiovasc Res 2001; 51: 495-509.

15 Vanderheyden M, Bartunek J, Goethals M. Brain and other natriuretic peptides: molecular aspects. Eur J Heart Fail 2004; 6: 261-268.

16 Mangiafico S, Costello-Boerrigter LC, Andersen IA, Cataliotti A, Burnett JC Jr. Neutral endopeptidase inhibition and the natriuretic peptide system: an evolving strategy in cardiovascular therapeutics. Eur Heart J 2013; 34: 886-893c.

17 Gardner DG, Chen S, Glenn DJ, Grigsby CL. Molecular biology of the natriuretic peptide system: implications for physiology and hypertension. Hypertension 2007; 49 . 419-426.

18 Potter LR, Abbey-Hosch S, Dickey DM. Natriuretic peptides, their receptors, and cyclic guanosine monophosphate-dependent signaling functions. Endocr Rev 2006; 27: 47-72.

19 Richards AM, Wittert GA, Crozier IG, Espiner EA, Yandle TG, Ikram H, Frampton C. Chronic inhibition of endopeptidase 24.11 in essential hypertension: evidence for enhanced atrial natriuretic peptide and angiotensin II. J Hypertens 1993; 11 407-416.

20 Boerrigter G, Burnett JC Jr.. Recent advances in natriuretic peptides in congestive heart failure. Expert Opin Investig Drugs 2004; 13: 643-652.

21 Potter LR, Yoder AR, Flora DR, Antos LK, Dickey DM. Natriuretic peptides: their structures, receptors, physiologic functions and therapeutic applications. Handb Exp Pharmacol 2009; 191: 341-366.

22 Renkin EM, Tucker VL. Atrial natriuretic peptide as a regulator of transvascular fluid balance. News Physiol Sci 1996; 11: 138-143. 
23 Brenner BM, Ballermann BJ, Gunning ME, Zeidel ML. Diverse biological actions of atrial natriuretic peptide. Physiol Rev 1990; 70: 665-699.

24 Baxter GF. The natriuretic peptides. Basic Res Cardiol 2004; 99: 71-75.

25 Chopra S, Baby C, Jacob JJ. Neuro-endocrine regulation of blood pressure. Indian J Endocrinol Metab 2011; 15(Suppl 4): S281-S288.

26 Kidney Disease Outcomes Quality Initiative (K/DOQI). NKF guidelines - Goals of antihypertensive therapy in CKD. Am J Kidney Dis 2004; 43 (Suppl 1): S65-S73.

27 Ruilope LM, Dukat A, Böhm M, Lacourcière Y, Gong J, Lefkowitz MP. Blood-pressure reduction with LCZ696, a novel dual-acting inhibitor of the angiotensin II receptor and neprilysin: a randomised, double-blind, placebo-controlled, active comparator study. Lancet 2010; 375: 1255-1266.

28 Kario K, Sun N, Chiang FT, Supasyndh O, Baek SH, Inubushi-Molessa A, Zhang Y, Gotou H, Lefkowitz M, Zhang J. Efficacy and safety of LCZ696, a first-in-Class angiotensin receptor neprilysin inhibitor, in Asian patients with hypertension: a randomized, double-blind, placebo-controlled study. Hypertension 2014; 63: 698-705.

29 Matsuo S, Imai E, Horio M, Yasuda Y, Tomita K, Nitta K, Yamagata K, Tomino Y, Yokoyama $\mathrm{H}$, Hishida A. Revised equations for estimated GFR from serum creatinine in Japan. Am J Kidney Dis 2009; 53: 982-992.

30 Williams B, Poulter NR, Brown MJ, Davis M, McInnes GT, Potter JF, Sever PS, McG Thom S. Guidelines for management of hypertension: report of the fourth working party of the British Hypertension Society, 2004-BHS IV. J Hum Hypertens 2004; 18: 139-185.

31 Gu J, Noe A, Chandra P, Al-Fayoumi S, Ligueros-Saylan M, Sarangapani R, Maahs S, Ksander G, Rigel DF, Jeng AY, Lin TH, Zheng W, Dole WP. Pharmacokinetics and pharmacodynamics of LCZ696, a novel dual-acting angiotensin receptor-neprilysin inhibitor (ARNi). J Clin Pharmacol 2010; 50: 401-414.

32 Kobalava Z, Pavlikova E, Averkov O, Moiseev V, Albrecht D, Feng A, Chandra P, Jordaan PJ. First experience with concomitant AT1 and neprilysin (NEP 24.11) inhibition with LCZ696 in patients with chronic heart failure. Circulation 2010; 122: A19378 (Abstract).

33 Mangrum AJ, Bakris GL. Angiotensin-converting enzyme inhibitors and angiotensin receptor blockers in chronic renal disease: safety issues. Semin Nephrol 2004; 24: $168-175$.

34 Peterson JC, Adler S, Burkart JM, Greene T, Hebert LA, Hunsicker LG, King AJ, Klahr S, Massry SG, Seifter JL. Blood pressure control, proteinuria, and the progression of renal disease. The Modification of Diet in Renal Disease Study. Ann Intern Med 1995; 123 : 754-762.

35 Solomon SD, Zile M, Pieske B, Voors A, Shah A, Kraigher-Krainer E, Shi V, Bransford T, Takeuchi M, Gong J, Lefkowitz M, Packer M, McMurray JJ. The angiotensin receptor neprilysin inhibitor LCZ696 in heart failure with preserved ejection fraction: a phase 2 double-blind randomised controlled trial. Lancet 2012; 380: 1387-1395.

36 Plum J, Bünten B, Nèmeth R, Grabensee B. Effects of the angiotensin II antagonist valsartan on blood pressure, proteinuria, and renal hemodynamics in patients with chronic renal failure and hypertension. J Am Soc Nephrol 1998; 9: 2223-2234.
37 Palmer BF. Angiotensin-converting enzyme inhibitors and angiotensin receptor blockers: what to do if the serum creatinine and/or serum potassium concentration rises. Nephrol Dial Transplant 2003; 18: 1973-1975.

38 O'Seaghdha CM, Perkovic V, Lam TH, McGinn S, Barzi F, Gu DF, Cass A, Suh I, Muntner P, Giles GG, Ueshima H, Woodward M, Huxley R. Blood pressure is a major risk factor for renal death: an analysis of 560352 participants from the AsiaPacific region. Hypertension 2009; 54: 509-515.

39 Tozawa M, Iseki K, Iseki C, Kinjo K, Ikemiya Y, Takishita S. Blood pressure predicts risk of developing end-stage renal disease in men and women. Hypertension 2003; 41: 1341-1345.

40 Martinez-Castelao A, Górriz JL, Portolés JM, De Alvaro F, Cases A, Luño J, Navarro-González JF, Montes R, De la Cruz-Troca JJ, Natarajan A, Batlle D. Baseline characteristics of patients with chronic kidney disease stage 3 and stage 4 in Spain: the MERENA observational cohort study. BMC Nephrol 2011; 12: 53.

41 Peralta CA, Hicks LS, Chertow GM, Ayanian JZ, Vittinghoff E, Lin F, Shlipak MG. Control of hypertension in adults with chronic kidney disease in the United States. Hypertension 2005; 45: 1119-1124.

42 Prøsch LK, Saelen MG, Gudmundsdottir H, Dyrbekk D, Hunderi OH, Arnesen E, Paulsen D, Skiønsberg $\mathrm{H}$, Os I. Blood pressure control is hard to achieve in patients with chronic renal failure: results from a survey of renal units in Norway. Scand J Urol Nephrol 2005; 39: 242-248.

43 Agarwal R. Blood pressure components and the risk for end-stage renal disease and death in chronic kidney disease. Clin J Am Soc Nephrol 2009; 4: 830-837.

44 Jafar TH, Stark PC, Schmid CH, Landa M, Maschio G, de Jong PE, de Zeeuw D, Shahinfar S, Toto R, Levey AS. Progression of chronic kidney disease: the role of blood pressure control, proteinuria, and angiotensin-converting enzyme inhibition: a patientlevel meta- analysis. Ann Intern Med 2003; 139: 244-252.

45 Kiberd BA, Larson TS, Robertson CR, Jamison RL. Effect of atrial natriuretic peptide on vasa recta blood flow in the rat. Am J Physiol 1987; 252: F1112-F1117.

cc)(1)(8) $\odot$ This work is licensed under a Creative Commons Attribution-NonCommercial-NoDerivs $\quad 4.0$ International License. The images or other third party material in this article are included in the article's Creative Commons license, unless indicated otherwise in the credit line; if the material is not included under the Creative Commons license, users will need to obtain permission from the license holder to reproduce the material. To view a copy of this license, visit http://creativecommons.org/licenses/ by-nc-nd/4.0/

Supplementary Information accompanies the paper on Hypertension Research website (http://www.nature.com/hr) 